Public Expenditure

Appraisal and Control. Edited by Alan T. Peacork and D. J. Robertson. Pp. viii + 168. (Edinburgh and London: Oliver and Boyd, 1963.) $21 s$.

7

HE publication as a soparate volume of the ten papers contributod to a symposium on the appraisal and control of public expenditure is timely when not morely the efficiency of Government control in general has beon brought in question, for example, by Prof. Brian Chapman in his rocent book, British Government Observed (Nature, 200, 198; 1963), but also the offectiveness of Government organization has been re-examined by the Trend Committoe.

Originally, the papers were published in the Scottish Journal of Political Economy, and while books by Basil Chubb and S. H. Beer have in recent years discussed the control of public expenditure from the administrative point of view, these papers concentrate on the oconomic side and indicate, for examplo, the value of Dr. $R$. McKoan's systems analysis in decisions on Government spending. Tho subject is ono which is likely to grow in importance, and as Prof. A. T. Poncock shows in his paper on "Economic Analysis and Government Exponditure Control", while the way forward has been pointod by tho Plowden Roport, for example, oxtonsive adoption of economio analysis is likoly to await a major change in the attitude of the electorato to public spending-or, it might be suggested, somo rational understanding between political parties.

The specific problems of defenco exponditure, health servioe policy, the allocation of expenditure in the electricity supply industry and the control of subsidy $\theta \mathrm{x}$ penditure in agrieulture are discussod by Dr. MoKean, Mr. J. Wiseman, Dr. R. L. Mook and Mr. G. F. B. Houston, respectively. Others deal with the appraisal of Govornmont purehasing, controlling the Government's wage bill and the growth of Govornment expenditure in tho United Kingdom sinco 1790. In discussing problems of expenditure control in local govornment, Mr. L. Boyle comments that many universities appear to have been singularly remiss in providing facilities for studying public finance and political science. Ho suggests that a much olosor contact is desirable between the acedemie world and the field of practice so that senior officials in tho publie service can communicate their probloms to the universitios, enabling research to bo conducted into those problems, and thoreafter benefiting from the results of such rosearch.

Such a romark itself attosts the significance of this volume to which Mrs. Ursula $K$. Hicks contributes an epilogus on choice, efficiency and control in the public services, which has some sound comments to make on the Plowdon Report.

\section{Experiments in Physical Chemistry}

By J. M. Wilson, R. J. Noweombo, Dr. A. R. Donaro and Dr. R. M. W. Rickett. Pp. xii +290 . (London and Now York: Pergamon Press, 1962.) 21s, net.

$T^{X P E R T M R N T S}$ in Physical Chemistry is intended for 4 use by students reading chemistry to honours degree standard. The form of presentation is most attractive. Each exporiment is assigned to one of three sections, the sections difforing in the degree of complexity of the operations and the nssoesiated theory.

Each oxperiment is profaced by a discussion of the theory involvod. The discussions aro incomplete but serve to relate the book with theoretical toxts. Next, the apporatus required is doseribod. Diagrams aro useful, and firms manufacturing the oquipmont to be used ore listed. The method to be followed is thon given, and here tho text is weak. More dotail is required; too much initiative is requirod of the student. For this reason the book might prove a valunble addition to the tosoher's library, the studont reaping the benofit second-hand.
Tho book has an officient indox and the contents are set out very clearly. One hundred and two experiments are presented and they are selected to cover the wide rango of physical theory and technique. Although most of the experiments are of college standard, there is a great deal here to interest the very able sixth-form pupil, and tho book would be a very usoful additional source of ideas for end-of-term laboratory work. D. C. Fintr

\section{Organic Chemistry Laboratory Operations}

By W. B. Renfrow and P. J. Hawkins. Pp. viii +216 . (New York: The Macmillan Company; London: Tho Macmillan Company, New York, 1962.) n.p.

7 HIS book eovors a very wide range of techniques.

Its introductory chapters on distillation, extraction, molting and boiling point determinations are familiar ground for a pupil in the lower sixth form. Tho final chapters on high-pressure hydrogenation and infra-rod spectroseopy are the province of an honours student in his final year.

A range of preparations aro given and these illustrato well the basic reaction types of organic chemistry. Many of the experimonts are done using unfamiliar materials. For example, $p$-xylene is sulphonated and not benzenos. Saturation and unsaturation are illustratod using cyclohexane and cyclohexono and not the more familiar mothane and ethylene. The general theme, worthy of close attention, is that reactants must be easy to handlo, reactions must work quickly, and the products be easy to isolate.

Each ohapter includes a discussion illustrated by olear diagrams; also an equation and a suggestod mechanism for the reaction. A problem is given at the ond of the chaptor and is designed to tost the student's understanding of the theory. Between theory and problem there is a method. This is adequate in earlier chaptors on olementary experiments, but quito the reverse later in the book when advanced work is under discussion. Students are asked to soo the instructor for working instructions !

The early part of tho book is well worth reading at the bench; the latter part has no place in the laboratory. D. C. Firth

Mild-Moderate Forms of Protein-Calorie Malnutrition Symposia of the Swedish Nutrition Foundation, Bastad, August 29-31, 1962. Editod for the Swedish Nutrition Foundation by Gunnar Blix. Pp. 159. (Stockholm: Almqvist and Wiksell, 1963.) Sw. Kr. 35.

TOWARDS the end of 1961, the Swedish Nutrition Foundation came into being, mainly through the financial support of the Swedish food industry. Among its projected activitios is an annual symposium. The first of those was held in August 1962. This book records the papers read then, and a summary of the discussion. There were 13 contributions, all by workers who had a direct concorn in the problem of protein-calorie deficiency. These included research workers from the United States of America, Africa and Central America, as well as a reprosentative from the World Health Organization and one from the Food and Agriculture Organization. The contributions dealt with tho clinical and biochemical features of the condition and with related questions such as protein and calorie requirements, mothods of assessmont of physical eondition, the use of protein-rich foods for prevontion, and an exhaustive and provocative article on the evaluation of the nutritive value of protein.

Together these papers form an excellent reviow of the present-day situation. Tho discussion is especially valuable in emphasizing how much we still have to loarn about this, the commonest of all forms of malnutrition. The book is boautifully produced and a ploasure to read. There are very fow and quite unimportant misprints, a most praiseworthy effort for a book produced and printed in Sweden. TOHN YUDKIN 